\title{
Lypsykarjan tehostetun terveydenhuoltotyön taloudellisuuden mittaaminen
}

\author{
Heikki Mäkinen \\ Taloustieteen laitos, PL 27, 00014 Helsingin yliopisto, \\ heikki.makinen@helsinki.fi.
}

Kotieläintilojen terveydenhuollolla tarkoitetaan eläinten terveyden ja hyvinvoinnin ylläpitämistä ja parantamista tuotannon kannattavuuden parantamiseksi. Alan tutkimuksessa tyypillisiä lähestymistapoja ovat empiiriseen aineistoon perustuvat laskelmat ja simuloinnit sairauksien vaikutuksista tuotantoon ja tuotantopäätöksiin.

Tutkimuksen tavoitteena oli selvittää, onko maidontuotannon taloudellisen tuloksen ja terveydenhuoltotyöhön osallistumisen välillä yhteyttä. Aineistona käytettiin Pro Agrian Laaja-MATU -laskelmia. Analyysiin poimittiin tilat, joille oli tehty L-MATU vuosina 1998 ja 2001. Terveydenhuoltohankkeisiin osallistuneita tiloja oli 58 (=th-tilat) ja vertailutiloja 184. Kannattavuuden seurannan tunnusluvuksi valittiin lehmäkohtainen maitotuotto sekä maitotuoton ja rehu-, siemennys-, lääkintä-, puhtaanapitoja uudistuskustannuksen erotus (=katetuotto).

Vuonna 1998 maitotuotto oli th-tiloilla keskimäärin $3804 €$ ja vertailutiloilla $3648 €$. Se kasvoi vuoteen 2001 mennessä th-tiloilla keskimäärin $371 €$ ja vertailutiloilla $248 €$. Ero oli tilastollisesti merkitsevä. Katetuotto vuonna 1998 oli th-tiloilla keskimäärin $2235 € /$ lehmä ja vertailutiloilla $2062 € /$ lehmä. Th-tiloilla katetuotto kasvoi vuoteen 2001 mennessä 2459 euroon ja vertailutiloilla 2212 euroon. Sekä lähtö- että lopputilanteessa ryhmien ero katetuoton tasossa oli tilastollisesti merkitsevä. Katetuoton muutos vuodesta 1998 vuoteen 2001 oli positiivinen 67 prosentilla th-tiloista ja 63 prosentilla vertailutiloista. Suuria negatiivisia muutoksia oli enemmän vertailuryhmässä ja positiivisia muutoksia thryhmässä. Muutoksen suuruus oli th-tiloilla keskimäärin $225 €(10,1 \%)$ ja vertailuryhmän tiloilla 149 $€(7,2 \%)$, ryhmien ero ei ollut tilastollisesti merkitsevä.

Kun katetuoton lähtötaso otettiin huomioon kovarianssianalyysin avulla, ryhmien välillä havaittiin merkitsevä ero. Regressiomallin sovitteeksi saatiin:

$$
\begin{array}{ll}
\text { th-ryhmä } & \text { katetuoton muutos }=1835,64-0,720828 * \text { lähtötaso } \\
\text { vertailuryhmä } & \text { katetuoton muutos }=956,238-0,391217 * \text { lähtötaso }
\end{array}
$$

Katetuoton lähtötaso ja th-hankkeeseen osallistuminen selittivät 25,7 \% katetuoton muutoksesta. Alhaiseen selitysasteeseen sopii estimaatin suuri keskivirhe 342 .

Tulosten mukaan ennakoivalla terveydenhuoltotyöllä oli mahdollista parantaa maidon katetuottoa. Suurin katetuoton kasvu saatiin th-tiloilla, joilla katetuotto lähtötilanteessa oli heikko, mikä taas saattaa johtua lehmien terveysongelmista. Tutkimus toi esille terveydenhuoltohankkeiden suunnittelun kannalta keskeisiä näkökohtia: 1) Tuotantoprosessin seurantaan ja muistiinpanojen tekemiseen tulee panostaa riittävästi, minimivaatimuksena on LaajaMATU-laskelmien teko vuosittain. 2) Terveydenhuoltotyön ja seurannan tulisi jatkua usean vuoden ajan. 3) Tutkimuksen kannalta hankkeisiin tulisi osallistua riittävästi tiloja, ja osallistumisen intensiteetti olisi määritettävä, lisäksi olisi koottava aineistoa viljelijöiden operatiivisesta toiminnasta ja tavoitteista. Myös yksittäisten tilojen tarkastelu tapaustutkimuksin olisi hyödyllistä.

Asiasanat: Terveydenhuollon ekonomia, terveydenhuolto, terveystaloustiede, maidontuotanto, katetuotto, MATU 


\section{Johdanto}

Tuotantoeläinten terveydenhuollolla tarkoitetaan eläinten terveyden ja hyvinvoinnin ylläpitämistä ja parantamista tuotannon kannattavuuden parantamiseksi (MMM 2000). Määritelmään sisältyy paradoksi: jatkuva paine kotieläintuotannon tuottavuuden parantamiseen on yksi keskeisimpiä syitä siihen, miksi hyvinvointiongelmia nykyaikaisessa maataloustuotannossa ylipäätään ilmenee (esim. Serpell ja Parsons 2001). Terveydenhoitotyöllä on haluttu vastata vaatimuksiin kotieläintuotannon eettisestä kestävyydestä ja eläinten hyvinvoinnista, sekä vahvistaa suomalaisen maidontuotannon imagoa eettisesti ja ekologisesti kestävänä tuotantomuotona. Lisäksi on huomattava, että tuotantoeläinten hyvinvointi on jo sinänsä merkittävä arvo, eikä sitä pidä nähdä pelkästään muiden tavoitteiden saavuttamista tukevana välinearvona. Lypsykarjan terveydenhuollon tehostamiseen tähtääviä hankkeita on toteutettu eri puolilla maata mm. neuvontajärjestöjen, meijereiden ja paikallisten eläinlääkärien aloitteesta.

Terveydenhuollon ekonomia on tieteenalana saamassa yhä suurempaa merkitystä päätöksenteon apuvälineenä eläinten sairauksien ja epidemioiden kontrolloinnissa eri tasoilla. On tullut tärkeäksi osoittaa myös taloudelliset perustelut sille, että eläinten hyvinvoinnin parantamiseen ja takaamiseen tarvitaan taloudellisia resursseja.

Tämän tutkimuksen tutkimusongelmana oli lypsykarjan järjestelmällisen terveydenhuoltotyön taloudellisen merkityksen mittaaminen tilatasolla. Tavoitteena oli selvittää, onko maidontuotannon taloudellisen tuloksen ja terveydenhuoltotyöhön osallistumisen välillä havaittavissa yhteyttä. Lisäksi tutkimuksessa pyrittiin hahmottelemaan näkökulmia, jotka olisi hyvä ottaa huomioon terveydenhuoltohankkeita ja niihin liittyvää tutkimusta suunniteltaessa.

Tuotantoeläinten sairauksien merkitys tuotannon taloudellisuudelle on ilmeinen. Sairaudet aiheuttavat hoitokustannuksia ja alentavat tuotosmääriä sekä tuotoksen arvoa. Sairauksien vuoksi tuotantoeläimiä joudutaan poistamaan aiemmin kuin olisi tuotannon kannalta järkevää, mikä lisää karjan uudistuskustannusta sekä huonontaa karjanjalostuksen tehokkuutta. Eläinten hyvinvointi ja tilan taloudellisten tavoitteiden saavuttaminen muodostavat hyvin monimutkaisen riippuvuuksien verkon, jossa yksittäisten tekijöiden vaikutusta on erittäin vaikea arvioida (esim. Østergaard ym. 2000).

Tutkimuksia tuotantoeläinten sairauksien vaikutuksista tuotantoon on tehty runsaasti. Usein niissä on tarkasteltu ensisijaisesti sairauksien tuotannollisia vaikutuksia, mutta myös vaikutuksia tilojen talouteen on pyritty analysoimaan. Tyypillisiä lähestymistapoja ovat empiiriseen aineistoon perustuvat laskelmat sairauksien havaituista vaikutuksista sekä toisaalta empiiristä dataa hyödyntävät simuloinnit ja mallinnukset, joilla pyritään arvioimaan sairauksien merkitystä tuotantopäätöksiin optimaaliseen tulokseen pyrittäessä. Erityisten terveydenhuolto-ohjelmien toteutuksesta ja seurannasta ei kuitenkaan ole julkaistu paljoakaan etenkään taloudellista analyysiä sisältäviä tutkimustuloksia. Terveydenhuolto-ohjelmien vaikuttavuuden vähäinen tutkimus on yllättävä huomio, sillä jo vuonna 1987 Howe ja McInerney (ref. Dijkhuizen ym. 1991) ja vuonna 1991 Dijkhuizen ym. totesivat, että karjatilojen terveydenhoitotyössä ollaan siirtymässä ns. palokuntatyöstä eli ilmenevien ongelmien hoitamisesta ennaltaehkäisevään työhön, joka on osa maatilojen suunnitelmallista, liikkeenjohdollista työtä. James (2005) tarkasteli laaja-alaisesti terveydenhuollon ja talouden yhteyksistä tehtyjä tutkimuksia, ja totesi, että eläinlääkinnän potentiaaliset hyödyt voidaan kunnolla saavuttaa vain, mikäli se liitetään osaksi tilojen suunnittelu- ja liikkeenjohtoprosessia. Tällainen näkökulma olisi pystyttävä viemään läpi institutionaalisella tasolla eläinlääkinnän parissa toimiville, ja kaikkien toimijoiden olisi luovuttava pelkästä ad hoc -tyyppisestä ongelmien hoidosta. (Vrt. myös Rougoor ym.,1999a).

\footnotetext{
Aineisto ja menetelmät

Tutkimuksen taustalla olleiden terveydenhuoltoprojektien käytännön toteutuksessa kunnaneläinlääkäri tai terveydenhuoltoeläinlääkäri tarkasteli yhdessä viljelijöiden kanssa karjan terveyteen liittyviä tekijöitä, ja laati näistä muistion, jossa kiinnitettiin huomiota havaittuihin ongelmakohtiin. sekä annettiin toimintaohjeita niiden korjaamisesta. Havainnot ja suositukset jaettiin neljään luokkaan: hedelmällisyys, ruokinta, utareterveys sekä olosuhteet ja jalkaterveys. Annetut suositukset olivat keskenään hyvin erityyppisiä. Niistä joidenkin toteuttaminen oli helppoa eikä aiheuttanut juurikaan lisäkustannuksia, esim. kiimantarkkailun parantaminen ja kuntoluokitus. Toisten toteuttaminen (esim. parsien ja ilmanvaihdon korjaaminen) taas olisi aiheuttanut merkittäviä muutoksia navetassa ja huomattavia lisäkustannuksia.

Tutkimusaineistona käytettiin Pro Agria -neuvontajärjestön LaajaMATU -laskelmien syöttö ja tulostietoja vuosilta 1997-2001. Jotta tuloksen kehittymistä ajan mittaan voitaisiin tarkastella, aineis-
} 
tosta poimittiin analyyseihin ne tilat, joille laskelma oli tehty sekä vuonna 1998 että 2001, mutta ei välttämättä vuosina 1999 ja 2000. Tilajoukkoa rajattiin ottamalla mukaan vain ne tilat, jotka sijoittuivat samojen maaseutukeskusten alueille kuin terveydenhuoltohankkeisiin osallistuneet tilatkin (=thtilat). Tällöin th-tilaryhmään jäi 58 tilaa ja vertailuryhmään 184 tilaa.

L-MATU-laskelmat sisältävät runsaiden syöttötietojen lisäksi muutamia maidontuotannon kannattavuutta kuvaavia tunnuslukuja, jotka eivät kuitenkaan olleet erityisen käyttökelpoisia tutkimusongelman ratkaisemisessa. Niiden laskemiseen liittyy useita kustannuseriä, jotka ovat terveydenhuoltotyöstä riippumattomia ja joiden vaihtelu on suurta tilojen välillä. Kannattavuuden seurannan tunnusluvuksi valittiin lopulta yksinkertainen lehmäkohtaisen maitotuotoksen ja rehu-, siemennys-, lääkintä-, puhtaanapito- ja uudistuskustannuksen erotus (=katetuotto). Lisäksi tarkasteltiin maitotuoton kehittymistä. Katetuoton vaihtelu oli sekä th- että vertailutilojen ryhmässä erittäin suurta kaikkina tarkasteluvuosina. Th-ryhmässä minimiarvot olivat korkeampia ja keskihajonta pienempi kuin vertailuryhmässä.

Tilaryhmien välisten erojen tilastollista merkitsevyyttä tarkasteltiin varianssianalyysillä. Terveydenhuoltotyöllä mahdollisesti saavutettava tuloksen paraneminen riippuu kuitenkin myös siitä, millä tasolla tulos on ennen th-hankkeeseen mukaan lähtemistä. Tilalla, jolla terveysongelmat ovat vähäisiä ei tilan maidon katetuotto voi juurikaan parantua terveydenhuoltotyöllä. Vastaavasti alhainen katetuotto saattaa selittyä osittain karjan terveysongelmilla, jolloin terveydenhuoltotyön potentiaalinen muutosvaikutus on suuri. Katetuoton lähtötason huomioimiseksi katetuoton muutosta analysoitiin kovarianssianalyysillä, jossa varianssianalyysin tulosta korjattiin katetuoton lähtötason tuomalla lisäinformaatiolla. Pyrittiin siis vastaamaan kysymykseen onko ryhmien välillä eroa katetuoton muutoksessa, kun ryhmien erilaiset lähtötasot otetaan huomioon. Kovarianssianalyysissä rakennetaan regressioanalyysillä kovariaatin osuus vastemuuttujan selittämisessä. Mallille saadaan selitysaste, joka kertoo kuinka hyvin testattu malli kykenee tutkittavaa ilmiötä selittämään.

\section{Tulokset ja tulosten tarkastelu}

Maitotuotto vuonna 1998 oli th-tiloilla keskimäärin $3804 €$ ja vertailuryhmän tiloilla $3648 €$, ero oli tilastollisesti merkitsevä $(\mathrm{F}=4,58, \mathrm{p}=0,033)$. Vuoteen 2001 mennessä maitotuotto nousi th-tiloilla 4175 euroon ja vertailutiloilla 3896 euroon $(\mathrm{F}=13,28, \mathrm{p}<0,001)$ (kuvio 1). Maitotuoton muutos vuodesta 1998 vuoteen 2001 oli th-tiloilla keskimäärin 371 euroa ja vertailutiloilla 248 euroa. Tilaryhmien välinen ero oli tilastollisesti merkitsevä $(F=5,52, \mathrm{p}<0,0196)$.

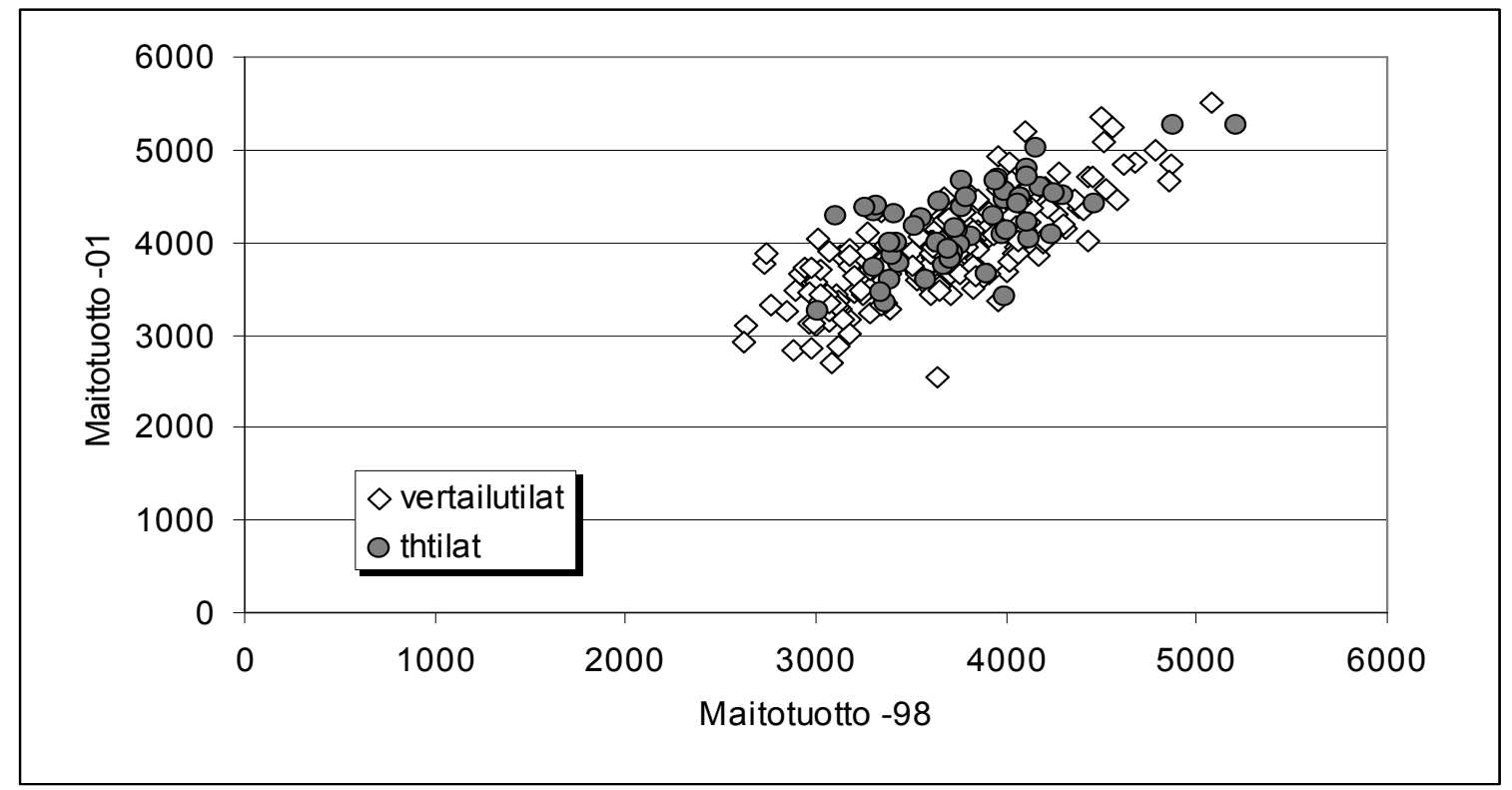

Kuvio 1. Maitotuotto €/lehmä vuosina 1998 ja 2001.

Katetuotto vuonna 1998 oli th-tiloilla keskimäärin $2235 € /$ lehmä ja vertailutiloilla 2062 $€ /$ lehmä. Th-tiloilla katetuotto kasvoi vuoteen 2001 mennessä keskimäärin 2459 euroon ja vertailutiloilla keskimäärin 2212 euroon. Katetuottojen sirontakuviot on esitetty kuviossa 2. Kuviosta käy ha- 
vainnollisesti ilmi, miten suurta hajonta katetuoton suhteen on, samoin kuin se, että ryhmittäiset sironnat ovat suurelta osin yhteneväiset. Vertailuryhmän th-ryhmää alempi katetuoton keskiarvo selittyy suurelta osin sillä, että siinä on sekä lähtö- että lopputilanteessa enemmän hyvin alhaisia katetuoton arvoja.

Lähtötilanteessa ryhmien ero katetuoton suuruuden suhteen oli tilastollisesti merkitsevä $(\mathrm{F}=6,76, \mathrm{p}=0,0099)$. Myös lopputilanteessa eli vuonna 2001 ero säilyi edelleen tilastollisesti merkitsevänä $(\mathrm{F}=15,16, \mathrm{p}<0,001)$. Th-projekteihin näyttää siten valikoituneen sellaisia maidontuottajia, joilla jo lähtötilanteessa keskimääräinen maitotuotto ja maidon katetuotto olivat suhteellisen korkealla tasolla.

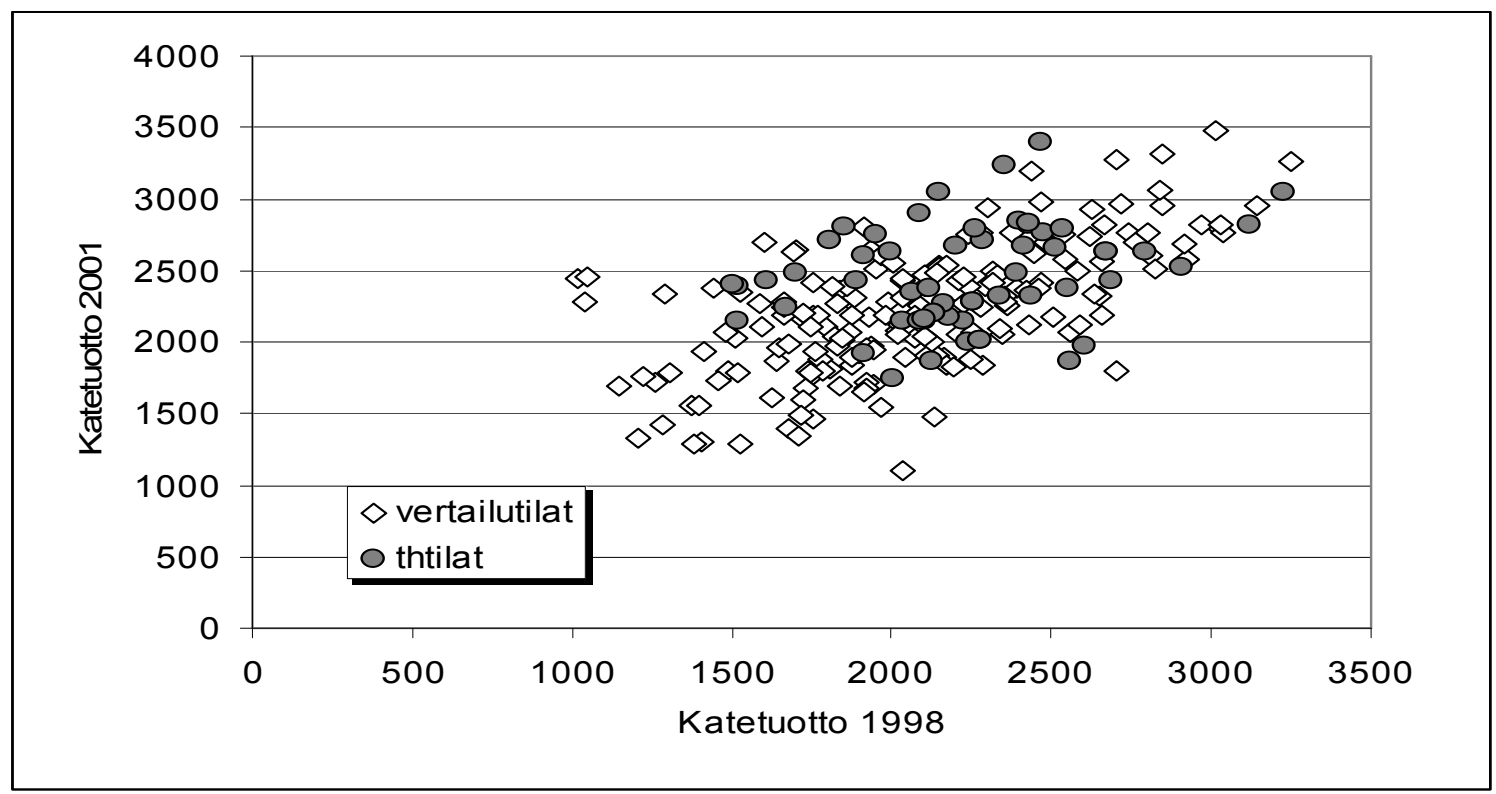

Kuvio 2. Katetuotto $€ /$ lehmä vuosina 1998 ja 2001.

Katetuoton tasoa mielekkäämpää on tarkastella sen muutosta ajan mittaan. Katetuoton muutos vuodesta 1998 vuoteen 2001 oli positiivinen 67 prosentilla th-tiloista ja 63 prosentilla vertailutiloista. Euromäärältään suuria negatiivisia muutoksia oli suhteellisesti enemmän vertailuryhmässä ja suuria positiivisia muutoksia th-ryhmässä. Muutoksen suuruus oli th-tiloilla keskimäärin $225 €$ eli 10,1 prosenttia ja vertailuryhmän tiloilla $149 €$ eli 7,2 prosenttia (kuvio 3). Ryhmien välinen ero katetuoton muutoksessa ei kuitenkaan ollut varianssianalyysin mukaan tilastollisesti merkitsevä $(\mathrm{F}=1,60$, $\mathrm{p}=0,207)$.

Kun katetuoton lähtötaso otettiin huomioon kovarianssianalyysin avulla, ryhmien välillä voitiin havaita tilastollisesti merkitsevä ero. Katetuoton muutosta selittävän regressiomallin sovitteeksi saatiin:

$$
\begin{array}{ll}
\text { th-ryhmä } & \text { katetuoton muutos }=1835,64-0,720828 * \text { lähtötaso } \\
\text { vertailuryhmä } & \text { katetuoton muutos }=956,238-0,391217 * \text { lähtötaso }
\end{array}
$$

Sirontakuviot regressiosuorineen on esitetty kuviossa 3. Mallin kaikki parametrit poikkesivat tilastollisesti merkitsevästi nollasta. Selittävillä muuttujilla oli tilastollisesti merkitsevä vaikutus katetuoton muutokseen $(\mathrm{F}=28,73 ; \mathrm{p}<0,001)$, mutta mallin korjattu selitysaste jäi varsin alhaiseksi ollen 0,257 . Katetuoton lähtötaso ja th-hankkeeseen osallistuminen selittivät siten 25,7 prosenttia havaitusta katetuoton muutoksesta. Mallin estimaatin keskivirhe oli 342, mikä sopii hyvin yhteen alhaisen selitysasteen kanssa, ja mallin jäännöstermit olivat normaalisti jakautuneita. Regressiomallin mukaan siis th-tilaryhmässä etenkin lähtötilanteessa alhaisen katetuoton saavuttaneet tilat olivat pystyneet parantamaan tulostaan, kun taas korkean katetuoton saavuttaneilla muutos oli pienempi. Sama säännönmukaisuus oli havaittavissa myös vertailuryhmässä, mutta ei yhtä voimakkaana. 


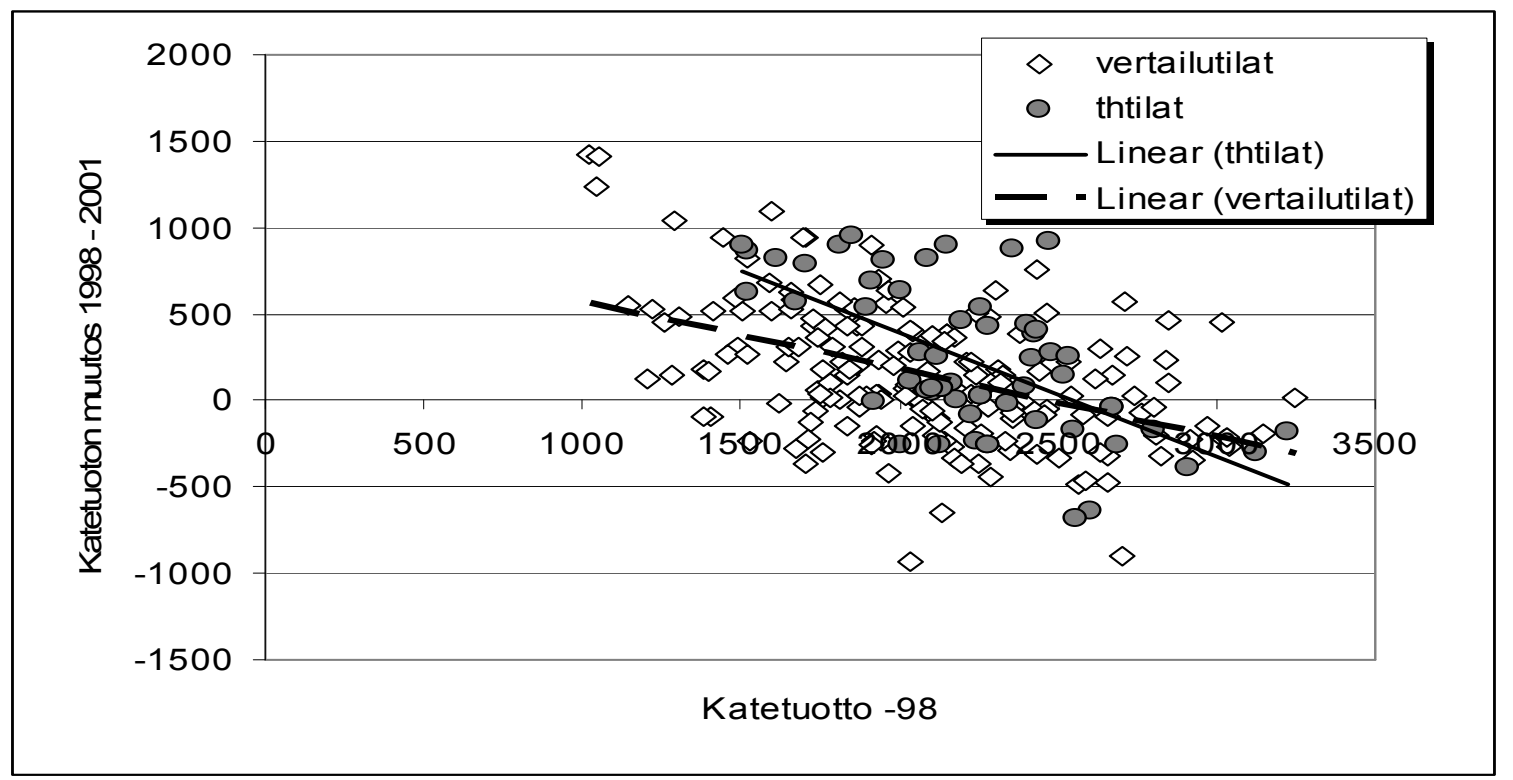

Kuvio 3. Katetuotto $€ /$ lehmä vuonna 1998 ja sen muutos vuoteen 2001 sekä kovarianssimallin regressiosuorat.

\section{Johtopäätökset}

Tutkimustulosten mukaan terveydenhuoltohankkeisiin osallistuneiden tilojen maidosta saama tuotto sekä katetuotto lehmää kohti olivat sekä tarkasteluajanjakson alussa että lopussa korkeampia kuin vertailuryhmän tiloilla. Kun tämä lähtökohta otettiin huomioon, voitiin todeta, että ennakoivan terveydenhuoltotyöllä oli mahdollista parantaa maidon katetuottoa. Mikäli muiden tilan tulokseen vaikuttavien tekijöiden vaikutus oletetaan vakioksi ajan suhteen, tämä merkitsee myös tilan kannattavuuden paranemista. Keskimäärin suurin katetuoton kasvu saavutettiin th-tiloilla, joilla katetuotto lähtötilanteessa oli heikko. Yhtenä syynä alhaiseen katetuottoon taas saattavat olla lehmien terveysongelmat. Näin ollen terveydenhuoltoprojektien voidaan katsoa olevan hyödyksi nimenomaan heikoimmin menestyneille tiloille. Katetuoton ja sen muutoksen vaihtelu oli kuitenkin molemmissa tilaryhmissä niin suurta ja riippuu niin monista tässä tutkimuksessa kontrolloimattomista tekijöistä, että päätelmiin tulee suhtautua varauksella

Tilojen luokitteleminen terveydenhuoltoprojekteihin osallistuneiksi tehtiin kaavamaisesti sillä perusteella, että tilalle oli tehty terveydenhuoltosuunnitelma vuosien 1998 - 2001 aikana. Luokittelu on hyvin todennäköinen virhelähde th-työn vaikuttavuutta arvioitaessa, sillä tällöin ohitetaan kokonaan th-projekteihin osallistumisen intensiivisyyden arviointi. Intensiivisyys voidaan vuorostaan jakaa tekniseen ja sisällölliseen intensiivisyyteen. Esim. jos tilalle oli rekisteröity yksi th-projektiin liittyvä eläinlääkärin vierailu syyskuulle 1998, tila luokiteltiin th-projektiin osallistuneeksi jatkossa yhtäläisesti kuin toinen tila, jolla eläinlääkärin käyntejä oli useita vuosien mittaan. Sisällöllisen intensiivisyyden arvioinnin ongelma taas liittyy eläinlääkärin tilakäyntien sisällön merkitykseen: onko perusteltua olettaa että kaikki viljelijät kykenivät analysoimaan eläinten terveystilaa ja siihen vaikuttavia tekijöitä yhdessä eläinlääkärin kanssa yhtäläisesti? Todennäköisempää on, että viljelijän ammattitaito etenkin kotieläinten hoidossa samoin kuin maidontuotannon rooli koko tilan taloudessa sekä tilan elinkaaren vaihe vaikuttavat hyvin merkittävästi siihen, miten eläinlääkärin tarjoamaa apua on hyödynnetty ja hänen antamiaan ohjeita on käytännössä noudatettu. Lisäksi toimenpidesuositusten toteuttaminen käytännössä on mitä suurimmassa määrin sidoksissa muihin lypsykarjan hoitoon liittyviin tekijöihin, kuten rehuntuotantoon, navetan teknisiin ominaisuuksiin, lypsytyön tekniikkaan jne., jotka kuitenkin jäivät tässä tutkimuksessa tarkastelun ulkopuolelle. Samaan ongelmakenttään kuuluu myös se seikka, että erilaisiin kehittämis- ja neuvontahankkeisiin osallistuvat tyypillisimmin ne yrittäjät, jotka muutenkin ovat aktiivisia toiminnan kehittäjiä. Tähän suuntaan viittaa tämän tutkimuksen tilaryhmien katetuoton ero jo lähtötilanteessa.

Tutkimusaineistoa analysoitaessa esiin nousi muutamia näkökohtia, joihin on hyvä kiinnittää huomiota, kun tilatason terveydenhuoltohankkeita suunnitellaan. Keskeisin näistä on, että tuotantoprosessin seurantaan ja tätä palvelevien tilakohtaisten muistiinpanojen tekemiseen tulee panostaa riittä- 
västi osana tilan koko talouden seurannan kehittämistä. Minimivaatimuksena voidaan pitää sitä, että sairauksista ja niiden hoidosta sekä ennalta ehkäisystä aiheutuvat kustannukset kirjataan järjestelmällisesti. Yleensä tuottoerät kuten maitotuotos tunnetaan hyvin, mutta taloudellisuuden analysointi vaatii myös kustannusten tuntemista.

Toiseksi terveydenhuoltotyön ja sen seurannan tulisi jatkua järjestelmällisesti useamman vuoden ajan. Poikkileikkaustarkastelut eivät yleensä tuota yrityksen kehittämistä palvelevaa tietoa, koska vuotuinen vaihtelu on suurta. Yrityksen talouden kehittymisestä saadaan oikeansuuntainen kuva vain pitkän aikavälin tarkasteluilla. Kolmanneksi, mikäli terveydenhuoltohankkeiden tuloksia halutaan tarkastella tieteellisen kritiikin kestävällä tavalla, tulisi hankkeisiin osallistuneita tiloja olla riittävän paljon, ja tilojen osallistumisintensiteetti olisi kyettävä määrittämään. Samoin olisi koottava havaintoaineistoa myös viljelijöiden operatiivisesta toiminnasta sekä pidemmän aikavälin tavoitteista ja suuntaviivoista. Tulosten analysoinnin kannalta myös yksittäisten tilojen tarkasteluun keskittyvät tapaustutkimukset saattaisivat olla käyttökelpoisia. Näiden avulla saataisiin tarkka kuva terveydenhuoltotyön vaikuttavuudesta erilaisilla tiloilla.

Terveydenhuoltohankkeiden tuloksellisuuden seuranta aiheuttaa lisätyötä tiloilla, mutta tällainen seuranta ja analysointi tulisi nähdä yhtenä keskeisimmistä tilan liikkeenjohdollisista tehtävistä. Siihen uhrattu aika on panostus tuotantoeläinten hyvinvointiin ja tilan toiminnan kehittämiseen.

\section{Kirjallisuus}

Cassel, E., Vough, L., Varnerb, M., Eickelberger, R., Manspeaker, J., Stewart, L., Douglass, S. \& Peters, R. 1994. A Demonstration Project of Interdisciplinary Dairy Herd Extension Advising Funded by Industry and Users. 3. Impact on Management Practices. J. Dairy Sci. 77:2461-2416.

Debertin, D. 1986. Agricultural Production Economics. New York. 366 s.

Dijkhuizen, A., Stelwagen, J. \& Renkema, J. 1985. Economic aspects of reproductive failure in dairy cattle. I. Financial loss at farm level. Preventive Veterinary Medicine Vol. 3, Is-sue 3: 251-263.

Dijkhuizen, A., Renkema, J. \& Stelwagen, J. 1991. Modelling to support animal health control. Ag-ricultural Economics vol 5, no. 3: 263-277.

Green, L., Hedges, V., Schukken, Y., Blowey, R. \& Packington, A. 2002. The Impact of Clinical Lameness on the Milk Yield of Dairy Cows. J. Dairy Sci. 85: 2250-2256

González-Recio, O., Pérez-Cabal, M. \& Alenda, R. 2004. Economic Value of Female Fertility and its Relationship with Profit in Spanish Dairy Cattle. J. Dairy Sci. 87:3053-3061.

Gröhn, Y., Rajala-Schultzb, P., Allorea, H., DeLorenzoa, M., Hertla, J. \& Galliganc, D. 2003. Op-timizing replacement of dairy cows: modeling the effects of diseases. Preventive Vet-erinary Medicine, vol. 61, Issue 1: 27-43.

Haapala, V., Hartikainen, K. Tuovinen, V. 2004. Terveydenhuoltotyön hyödyt. Suomen eläinterveydenhuolto SETH. $39 \mathrm{~s}$.

Hall, D., Ehuib, S. \&.Shapiro, B. 2004. Economic analysis of the impact of adopting herd health control programs on smallholder dairy farms in Central Thailand. Agricultural Eco-nomics 31: 335-342.

Harsh, S., Connor, L. \& Schwab, G. 1981. Managing the Farm Business. 384 s.

Heikkilä, A-M. 1999. Poikimavälin pituuden taloudelliset vaikutukset. Maatalouden taloudellisen tutk.lait. tutkimuksia 236:1-54.

Howe, K.S. \& McInerney, J.P. (toim.), 1987. Disease in Livestock: Economics and Policy. EUR 11285 EN, Commission of the European Communities, Bryssel, $19 \mathrm{~s}$.

Hsiao, C. 2003. Analysis of Panel Data. Toinen painos. Cambridge. 366 s.

James, A. 2004. The state of veterinary epidemiology and economics. Preventive Veterinary Medi-cine 67: 9199.

James, S. ja Eberle, P. 2000. Economic \& Business Principles in Farm Planning \& Production. Ames, Iowa. $413 \mathrm{~s}$.

Kinnunen, U. \& Leskinen, E. 1989. Teacher stress during a schoolyear: Covariance and mean struc-ture analyses. J. Of Occupational Psychology, 62: 111-122.

Latvala, V. 1995. Tehostetun terveydenhuoltoneuvonnan yhteys sikaloiden kannattavuuteen eräissä EteläPohjanmaan sikaloissa. Maatalouden liiketaloustieteen pro gradu -työ. Helsingin yliopisto, Taloustieteen laitos. $64 \mathrm{~s}$.

MMM 2000. Tuotantoeläinten terveydenhuolto.. Maa- ja metsätalousministeriö, Työryhmämuistio 2000:9. Helsinki.

Mäkimattila, M. 1998. Sikojen hyvinvointi ja sen vaikutus sianlihan tuotantokustannukseen eri tuotantomenetelmissä. Maatalouden liiketaloustieteen pro gradu -työ. Helsingin yliopisto, Taloustieteen laitos. $87 \mathrm{~s}$. Niemi, J. 2002. Eläintautiriskien ekonomia. MTT:n selvityksiä 12: 1-39. 
Otte, M. \& Chilonda, P. 2000. animal Health Economics: an Introduction. FAO. 12 s. (Internet: http://www.fao.org/ag/againfo/resources/en/pubs_ah.html\#4).

Rajala-Schultz, P. \& Gröhn, Y. 2001. Comparison of economically optimized culling recommenda-tions and actual culling decisions of Finnish Ayrshire cows. Preventive Veterinary Medicine vol. 49, Issues 1-2: 29-39.

Rougoor, C., Hanekamp, W., Dijkhuizen, A, Nielen, M. \& Wilmink, J. 1999a. Relationships be-tween dairy cow mastitis and fertility management and farm performance. Preventive Veterinary Medicine 39: 247-264.

Rougoor, C., Huirne, R. Dijkhuizen, A., Mandersloota, F. 1999b. Repeatability in ranking of dairy farms on technical and economic performance over years. Preventive Veterinary Medicine 38: 25-34.

Ryhänen, M., Sipiläinen, T., Ylätalo, M. \& Koskiahde, M. 1998. Vieremän kunnan maatilojen re-surssit ja niiden siirtymä vuosina 1985 - 1995. Teoksessa Ryhänen, M., Sipiläinen, T., Ylätalo, M. (toim.) 1998. Maatilojen tuotanto ja talous Vieremän kunnassa vuosina 1985 - 2000. Helsingin yliopisto, Taloustieteen laitos. Julkaisuja nro 21: 27-71.

Serpell, J. \& Parsons, T. 2001. Food Animal Husbandry and the New Millennium. J. of Applied Animal Welfare Science vol. 4(3): 169-173.

Sihvonen, T. 1993. Kotieläintuotteiden ja -tuotannon eettisyys taloudellisena tekijänä. Maatalous-politiikan pro gradu -työ. Helsingin yliopisto. $95 \mathrm{~s}$.

Thompson, P. 2001. Animal Welfare and Livestock production in a Postindustrial Milieu. J. of Ap-plied Animal Welfare Science 4(3): 191-205.

Toikka, V. 2000. Etelä-Pohjanmaan lypsykarjojen terveydenhuoltoprojektin tuloksia vuosilta 1998-1999. $12 \mathrm{~s}$. Tölli, M. 2004. Terveydenhuoltotyön onnistuminen tilallisten näkökulmasta. Opinnäytetyö, Helsingin yliopiston kotieläinhygienian laitos. Käsikirjoitus. 7 s.

Warren, M. 1998. Banishing 'fixed' and 'variable' Costs: Time to Bring Farm Accounting into the Real World. Farm Management vol. 10, no. 2: 75-79.

Wells, S., Ott, L. \& Seitzinger, A. H. 1998. Symposium: Emerging Health Issues. Key Health Is-sues for Dairy Cattle-New and Old. J. Dairy Sci. 81:3029-3035

Østergaard, S., Sørensen, J. \& Kristensen, A. 2000. A Stochastic Model Simulating the Feeding-HealthProduction Complex in a Dairy Herd. J. of Dairy Science 83: 721-733. 